\title{
Proposal for Saudi Universities Governance in the Light of Principles of Organization for Economic Cooperation and Development
}

\author{
Talal A. Alsharif (Corresponding author) \\ Educational Sciences Department, Faculty of Education \\ Shaqra University, Saudi Arabia \\ E-mail: alshreef-talal@su.edu.sa
}

Received: March 25, 2019 Accepted: April 27, 2019 Published: May 7, 2019

doi:10.5296/jei.v5i1.14561ＵRL: https://doi.org/10.5296/jei.v5i1.14561

\begin{abstract}
The current study aimed at identifying the indicators of practicing governance in Saudi universities in the light of the principles of Organization for Economic Cooperation and Development (OECD). It also underlined the challenges facing governance practice and introduced a proposal for governance principles in Saudi universities. Descriptive approach utilized and a questionnaire applied to a random stratified sample consisting of 113 Deans from various Saudi universities. Results indicated that the indicators of practicing governance in Saudi universities in the light of (OECD) principles are (medium). Challenges facing the practice of governance in Saudi universities obtained a high degree. Education experts agree on the appropriateness of the proposed principles for university governance by $99 \%$. The study recommended the necessity of activating the practice of governance principles in various activities and processes of universities.
\end{abstract}

Keywords: Saudi universities, Governance practice, OCED principles

\section{Introduction}

Over the past few decades, the concept of governance has become one of the dominant themes in both private and public institutions because of the financial crises they experienced. Institutions worldwide have witnessed administrative, accounting and financial corruption resulting from poor practice of effective governance in planning, control and supervision. It leads to lack of confidence in these institutions and the call for attention to the concept of governance. In 1999, OECD has set up the principles of corporate governance in United States and they were developed in 2004. In its report issued in 1992, Cadbury Commission has 
developed a framework for corporate governance principles in Britain. Governance concepts have become a global trend because of its importance in achieving performance quality and excellence in the public sector, in general, and universities, in particular. Governance perceived as a key quality standard for universities (Muhammad, 2011).

Many studies and conferences have recommended the importance of adopting the principles of governance. In their report Henard and Mitterle (2008), agree that governance plays a significant role in efficiently achieving university functions, performance quality and excellence and balance between independence and participation. Al-Abbas (2009) believes that Saudi Universities should be concerned with applying the principles of governance because of its far-reaching effects on the vital sector of universities. Nasreddin (2012) noted that the application of governance enhances the concepts of transparency and accountability. University governance contributes to achieving organizational efficiency and effectiveness, producing competitive education and facing contemporary challenges. Al-Farra (2013) emphasized the importance of reviewing governance rules, principles, and degree of application. Universities objectives and strategic plans should be amended in accordance with governance requirements. Al-Arini (2014) recommended issuing university governance principles, enforcing their practice on universities departments and councils, forming committees to follow up on their implementation and establishing effective organizational structures to achieve substantive balance between the responsibilities and powers. Al-Fawzan (2017) ensures that applying corporate governance in Saudi universities contributes to achieving Vision 2030, determining accountability standards, building effective organizational structures and benefiting from international universities experiences in the field of governance.

On the contrary, Shehata (2001), Arab Human Development Report on University Education (2003), Muhammad (2006), Ghaleb and Alem (2008), Glenn (2008), Altwaijri (2009) and Jezierska (2009) refer to weakness in the quality of university education. Furthermore, there is no study about applying the principles of corporate governance in high education. Hence, there is a need to conduct a study to identify the indicators of practicing governance in Saudi universities in the light of the principles of OECD.

\section{Statement of the Problem}

The study problem can be determined by absence of governance practices in Saudi universities, as there are many challenges hindering their application. Saudi universities should adopt the principles of governance in the management of its activities as they play a basic role in community leadership towards development and progress. Governance is an effective management method that deepens the understanding of quality concepts and university excellence. The study problem can be formulated in the following questions:

\subsection{Questions}

1) What are the indicators of practicing governance in Saudi universities in the light of the principles of OECD?

2) What are the challenges facing governance practice in Saudi universities? 


\section{Macrothink}

3) What are the proposed principles for governance in Saudi universities?

\section{Objectives:}

The current study aimed at:

1) Identifying the indicators of practicing governance in Saudi universities in the light of the principles of OECD.

2) Identifying the challenges facing governance practice in Saudi universities.

3) Proposing principles for governance in Saudi universities.

\section{Significance}

1) An objective response to the call for practicing governance principles and its effective impact on universities performance.

2) Providing a questionnaire for measuring the indicators of practicing governance in Saudi universities in the light of the principles of OECD.

3) Presenting a proposal for the principles of governance in Saudi universities.

4) Investigating the reality of practicing governance indicators in Saudi universities in the light of the principles of OECD.

5) Reflecting the development of governance principles in the public sector, in general, and in universities, in particular.

\section{Limitation}

1) Spatial and human limitation: (9) Saudi universities: King Abdulaziz University, Umm Al-Qura University, King Khalid University, Shaqra University, Qassim University, Al-Jouf University, King Faisal University and Princess Nourah University.

2) Temporal limitation: $2017 / 2018$.

3) Objective limitation: Indicators of practicing governance in Saudi universities and the challenges hindering its application and presenting a proposal for the principles of university governance from the perspective of colleges deans in the universities under study.

\section{Theoretical Framework}

\subsection{The Emergence of Governance:}

In his lectures at the Collège de France in 1977, prof. Michel Foucault was the first to develop the concept of governance. He defined it as the art to government, which is not limited to state politics, but includes a range of controls, beginning from self-control to the control of populations Mohammed (2011).

The concept of governance has emerged when economists called for the optimal use of resources with relevance to colleges and corporations governance. Its emergence accompanied the water-gate issue in USA, resulting the failure of financial control and the absence of 
disclosure, transparency and accountability. In response to many studies on the decline of economic institutions, the concept of governance has been clearly established in 1999 (Abu Bakr, 2005).

Governance, governmentality or effective governance refers to the management of control that promotes human well-being and expands his/her capabilities and political, economic social and cultural freedom. The concept of governance has been spread and applied to the other fields of the public sector (Abdullah, 2009).

It can be excluded that concepts, principles and practices of governance have been developed during the last two decades in response to the financial crisis that led to the decline of many economic institutions all over the world.

\subsection{The Concept of Governance:}

The International Finance Corporation (IFC) defines corporate governance as the structures and processes for the direction and control of companies (Youssef, 2007).

OECD defines it as a group of relationships among those in charge of administering the corporation, the board of directors, shareholders and other contributors (Youssef, 2007).

Gawdat (2008) defines it as a comprehensive system that compromises the measures of effective management performance and indicators of control methods that prevent any internal or external party from adversely affecting the activities of the institution and thereby ensuring the optimal use of the available resources to serve all parties interests evenly.

Ghader (2012) perceives it as a set of procedures and processes through which organizations are guided and controlled, establishing a framework that guarantees the identification of rights and distribution and responsibilities among stakeholders, Board of Directors, shareholders and other contributors. Governance helps set up the procedures of decision-making processes and promote the culture of responsibility through devising a system for measurement, evaluation and improvement.

Accordingly, governance can be defined as a range of regulations, procedures and control systems governing relations between stakeholders in Saudi universities in order to enhance transparency, justice and accountability and to achieve strategic objectives, quality and excellence in administrative, academic research and community development performance.

\subsection{Governance Features (Marzouk, 2012)}

$\checkmark$ Providing the opportunity to participate in the decision-making process;

$\checkmark$ Providing equal opportunities to all stakeholders;

$\checkmark$ Following-up the implementation of objectives;

$\checkmark$ Monitoring decision-makers;

$\checkmark$ Focusing on the scope of supervision and follow-up;

$\checkmark$ Utilizing resources in a distinctive manner; 


\section{Macrothink}

$\checkmark$ Ensuring the sustainability of comprehensive development and the flow of information to all parties.

6.4 Governance Objectives (Al-Kayed, 2003; Bilal, 2005)

$\checkmark$ Enhancing Justice and fair treatment among all stakeholders;

$\checkmark$ Protecting their rights and preventing the exploitation of power;

$\checkmark$ Encouraging and attracting investments and the flow of funds;

$\checkmark$ Strengthening integrity, transparency and efficiency;

$\checkmark$ Enhancing legitimacy, responsibility, equality and accountability in society.

The success of governance practice depends on the awareness of its importance, concepts, objectives and features, taking into account the importance of disseminating them as an integral part of the institutions culture and relevant to the level of achievement and quality.

\subsection{Governance in Universities}

The positive impact of corporate governance has led to the transfer of the concept of governance practice, as an administrative technique, to universities. Applying governance principles may contribute to solving many financial and administrative problems, organizing relationships and establishing accurate standards of work, follow-up and participation among all parties in universities. The absence of governance in administrative, academic and research practices in universities has led to absence of genuine participation by stakeholders, mainly students, faculty, community institutions and beneficiaries of the University's services in general (Al-Taei \& Hamad, 2010).

USA is the first country to apply corporate governance in universities to improve administrative methods, activate control systems, ensure a good level of university performance, support university-based decisions, and support decentralization and self-management (Yang, 2007).

OCED (2010) pointed out that governance in higher education covers many practices relevant to the cohesion of the components of the institution. It includes how to exercise power, contact internal and external members, take decisions, distribute responsibility, arrange internal procedures, determine the role of the councils of departments, colleges and the university and the role of Rectors and Deans, allocate resources and prepare follow-up reports.

\subsection{Significance of University Governance}

$\checkmark \quad$ Introducing new mechanisms to assess and interpret the university politics, raising the level of participation in decision-making processes, organizing the nature of relationships between individuals and policy-makers, and providing different patterns of communication that contribute to policy formation (Marzouk, 2011). 
$\checkmark$ Improving the educational level and conducting administrative reform as it protects the rights of the parties, ensures transparency and optimal utilization of resources, reduces costs and expenses and disseminates confidence in work environment (Hamada, 2010).

Developing sound strategy, ensuring effective decision-making, avoiding any risks or conflicts within the university, improving performance quality and institution reputation, enhancing administrative practices and committing to the best standards (Dahawi \& Bioumy, 2011).

$\checkmark \quad$ Promoting university administrative and financial management (Nassereldeen, 2012).

$\checkmark$ Establishing independent institutions with governing bodies and councils responsible for determining the strategic trend, enhancing competitiveness and avoiding administrative, financial and academic corruption (Al-Arini, 2014).

Governance is a contemporary requirement for universities as the leading public institutions that set up sustainable development programs and drive socio-cultural progress. Consequently, developing universities governance principles are required to be in accordance with their roles in development, the nature of their work and their relations with various stakeholders.

\subsection{University Governance Models (Al-Essa et al., 2013)}

$\checkmark$ Academic governance: It is the most common traditional model through which the university is administrated by faculty members.

$\checkmark$ Corporate governance: University politics, planning and effective administration are carried out by experienced specialists.

$\checkmark$ Trustee governance: University is run by a trustee board that acts on behalf of beneficiaries.

$\checkmark \quad$ Stakeholder governance: University is internally and externally administrated by a wide array of stakeholders, including students, faculty, government, society members, etc.

$\checkmark$ Amalgam governance: A mixture of all previous governance models.

$\checkmark$ Benchmarking governance: A modern model that flexibly links the institution components through quick adaptation to the needs of beneficiaries.

\subsection{Public Sector Governance Challenges (Hafez, 2011)}

$\checkmark$ Incompliance with professional standards.

$\checkmark$ Low officials have control on departments.

$\checkmark$ Officials are unconvinced with governance programs.

$\checkmark$ Lack of many governance concepts, including free responses, accountability and transparency, compliance with laws, availability of mechanisms, and anti-corruption measures.

$\checkmark$ Poor laws and regulations organizing work. 
6.9 University Governance Challenges (Ezzat, 2009)

$\checkmark$ Prevalence of negative culture which not conducive to dialogue and participation.

$\checkmark \quad$ Focus on certificates and lack of initiative.

$\checkmark$ University leaders are appointed, instead of being elected.

$\checkmark$ Low participation of faculty in decision-making and policy-making and weak role of faculty social clubs.

\subsection{Principles of OECD}

In 2004, OECD has developed six principles for corporate governance (Abu Dhabi Governance Center, 2016):

$\checkmark$ Institutional framework of effective corporate governance: including a set of legislations, laws, regulations, contracts and rules that enable the self-governing establishments to work as the main component of the competitive market economy and the implementation of internal corporations' governance.

$\checkmark$ Shareholders rights: including rights of ensuring secure ownership of shares, ample disclosure of information, voting rights, participation in the decision of selling or modifying the corporation's assets and shares.

Equal treatment of shareholders: through protecting minor shareholders' rights and preventing employees within the corporation from benefiting from their positions.

$\checkmark$ Other beneficiaries' role in the corporate governance: such as banks, bonds holders and employees who are important beneficiaries to the corporation's methods of conducting work and making decisions.

$\checkmark$ Disclosure and transparency: through devised reports on the corporation's financial details, governance structures, bounces, and annual auditing by two independent auditors according to the highest criteria of quality.

$\checkmark$ Responsibilities of board of directors: protecting the corporation, its shareholders and other beneficiaries as well as setting-up the corporation's strategy, risks, the performance of executive employees and their salaries, accounting systems and preparation of independent reports.

\section{Literature Review}

The information network on education in Europe Eurydice (2008) conducted study that aimed at providing a comparative and deep understanding of national regulatory frameworks of governance practices in the educational institutions. It concluded that higher education institutions are still following organizational and supervisory models of the state. their financial sources are based on public resources, resulting in a lack of participation, democracy, and financial and administrative autonomy. Allowing autonomy of higher education institutions and assigning an external supervisory body shall enhance transparency, 
accountability, motivation and competition.

Henard and Mitterle (2008) aimed at identifying the principles for practicing effective governance and how to distinguish between governance principles and quality standards. It concluded that governance has become a major tool for improving higher education quality and balancing between self-governance and accountability resulting from achieving consistency in the departments of the institution.

Al-Abbas (2009) aimed to define governance and its international standards, and the practices of university governance in Saudi Arabia through benchmarking with Arab and international universities. It emphasized the importance of practicing corporate governance in universities and its positive impact on higher education sector in Saudi Arabia. However, there is weak practice of governance principles at Saudi Universities compared to other universities.

Shunnaq (2009) aimed at identifying the concept of governance and the degree of practicing it among university leaders in Jordon. Results concluded that the level of academic administration understanding of governance concept and domains was a high. There were statistically significant differences in the degree of practicing governance principles, favoring faculty members in transparency principle.

Kpis (2009) dealt with the basic principles of public universities governance in Malaysia. It concluded that the factors of successful governance include competitiveness, resources, processes, continuing education, development, clear accountability, transparency, honesty and trust.

Wang (2010) investigated university independence by studying respondents' views on a questionnaire that covered university regulations, organizational departments and relation to the state. It discussed the mechanisms of Chinese government and the Communist Party control on higher education. Results concluded that applying governance principles of transparency, participation and accountability increased creativity, innovation, progress and learning outputs.

Mok (2010) investigated how academics assess the application of governance and its impact on university development. Although the senior management of universities has been given more discretion to decide how to operate their universities, most academics feel more pressures and control from the university administration and government ministries. They still see the state's reluctance in withdrawing from controlling higher education development. Nevertheless, the governments of Singapore and Malaysia are seeking to adopt governance practices in universities.

Mungiu and Dusu (2011) aimed at evaluating (430) public universities based on methodology in terms of administrative and academic integrity, democratic governance, academic governance and sound finance. Results revealed systemic problems in the organization and functioning of university life due to the failure to build accountability systems at university level following decentralization of higher education for a better public image, and therefore for reform of their practices. 
Al-Zahrani (2011) aimed at identifying the reality of applying governance principles in Saudi private universities and the degree of job satisfaction, organizational loyalty and relationships among employees according to some variables. Results concluded that there is a high degree of practicing governance in private Saudi universities and employees have a high degree of job satisfaction and organizational loyalty.

Barqan and Al-Qurashi (2012) aimed at highlighting the role of universities in achieving transparency and fairness, and how university administration adopts governance principles to face contemporary challenges. Results indicated that university governance contributes to establishing independent institutions responsible for determining their strategic objectives and ensuring the effectiveness of their management. University governance helps leaderships monitor, implement and evaluate performance efficiency.

Al-Farra (2013) aimed at understanding the reality of Palestinian universities governance and the challenges facing them. Results concluded that university visions and plans are not constantly updated and there are no mechanisms to ensure their application. In addition, there is a poor culture of accountability and lack of assessments mechanisms.

The Arab Organization for Education, Culture and Science (2013) aimed at analyzing the prevailing governance styles in the educational systems. It also aimed at identifying their impact on educational institutions management and contribution to developing a vision for effective educational leadership suitable for Arab reality. It concluded that there are deficits in practicing governance in the Arab educational system, as manifested in imbalances in educational leadership styles and in the manner of the educational system management, failure to apply decentralization, poor participation by stakeholders and inadequacy of administrative structures.

Al-Arini (2014) aimed at understanding the reality of applying governance and the challenges faced by the university. Results concluded that there a medium degree of applying governance at the University of Imam Muhammad bin Saud. There are statistically significant differences among the sample responses due to academic qualification, experience and position. The study recommended issuing regulations and legislations concerning the standards and principles of university governance and establishing committees to implement and follow up them.

Sharaf (2015) aimed at identifying the reality of applying governance systems in Palestinian universities, its obstacles and impact in the light of some variables. Results concluded that the sample responses show a high degree of applying governance and a medium of the obstacles. There were statistically significant differences in the reality and obstacles of applying governance due to the university variable. The study recommended developing binding laws for governance and strengthening control.

It can be extracted that previous studies have tackled the importance of activating governance in universities, identifying its standards, its reality, degree of practice, the challenges it faces, its role in achieving administrative and financial independence, and reducing governmental interventions in university performance, while relying on almost full governmental support and funding in developing countries. Governance styles in educational systems and some 
comparisons between governance systems in a number of European and Asian countries are covered. Studies revealed medium and weak degree of applying governance principles in higher education systems, including, accountability, transparency and justice. Attention should be given to governance through developing its existing legislation and developing special standards for universities.

The current study is interested in examining university governance, identifying its reality, degree of practice and the obstacles that limit its effectiveness. It is the first study to be applied to a large number of Saudi universities, (9) old and newly established Saudi universities. It contributes to establishing a comprehensive image about the practice of governance in Saudi universities, since the study population compromises university leaderships who carry the responsibility of practicing governance. The study finally aims to present a proposal for the principles of governance in Saudi universities.

\section{Methodology}

\subsection{Method}

The descriptive approach utilized to examine the reality of practicing governance in Saudi universities in the light of the principles of OECD. Comparative descriptive utilized to identify the statistically significant differences between the mean sample responses, according to university, gender, years of experience variables.

\subsection{Sampling}

$\checkmark$ Population: It consists of the deans of the nine colleges of Saudi universities under study, i.e., (223) Dean, according to the statistics of Deanship of Faculty Affairs in these universities in the second semester of 2017/2018.

$\checkmark$ Sample: A stratified random sample of about $50 \%$ of the study population was selected from the deans of the nine colleges of Saudi universities under study. It consisted of (113) Dean (14 Dean from King Saud University, 18 Dean from King Abdul Aziz University, 15 Dean from King Khalid University, 14 Dean from Qassim University, 8 Deans from King Faisal University, 13 Dean from Shaqra University, 10 Deans from Jouf University, 7 Deans from Princess Noura University).

\subsection{Tool}

After reviewing literature related to the study problem and the principles of OECD, a questionnaire prepared to identify the indicators of practicing governance in Saudi universities in the light of the principles of OECD. To check the psychometric characteristics of the questionnaire, it was applied to a pilot sample consisting of 27 deans, i.e., 3 deans from each university.

\subsection{Validity}

$\checkmark$ External validity: The initial form of the questionnaire was presented to a set of examiners to check the validity of the questionnaire items, in terms of its relevance, clarity, appropriateness to measure the domain, and linguistic soundness. Based on the opinion of the 
examiners on the appropriateness of the questionnaire items for the objectives of the study, some items have been modified. The total number of the questionnaire items were (80): 65 for the first domain and 15 for the second domain.

$\checkmark \quad$ Internal validity: correlation coefficient between the pilot sample score at each item and the total score of the principle (six principles)/challenges was calculated. Correlation coefficients ranged from $(0.67$ to 0.71$)$, i.e., they are statistically significant at $(0.05)$ indicating the questionnaire validity.

\subsection{Reliability}

Cronbach's Alpha calculated and the results ranged values between (0.85-0.92), indicating that the questionnaire has a high degree of reliability.

The final form of the questionnaire included 80 items divided into two main domains: principles of OECD and challenges. Five-point Likert scale utilized to analyze the sample responses to the questionnaire. (Very high) response with mean response (4.21-5) given (5), (high) response with mean response (3.41 and less than 4.21) got (4), (medium) response with mean response (2.61 and less than 3.41) obtained (3), (low) response with mean response and class (1.81 and less than 2.61) got (2), and (very low) response with mean response (1 and 1.81) obtained (1). The following criterion utilized for analyzing response score:

$$
\text { Response range }=\text { The highest score }- \text { The lowest score }=5-1=4
$$

Category length $=$ Response range/Number of response categories $=4 / 5=0.8$

\section{Results and Discussion}

To answer the first Question: What are the indicators of practicing governance in Saudi universities in the light of the principles of OECD? The mean and the standard deviation of the sample responses to the indicators of practicing governance in Saudi universities in the light of the principles of OECD were calculated. 


\section{Macrothink}

Table 1. Mean and standard deviations of the indicators of practicing governance in Saudi universities in the light of the principles of OCED

\begin{tabular}{|l|l|l|l|l|l|}
\hline S. & Principles & Mean & Std. deviation & Response & Ranking \\
\hline 1 & $\begin{array}{l}\text { Institutional Framework of Effective } \\
\text { Corporate Governance }\end{array}$ & 2.30 & 0.43 & Low & 5 \\
\hline 2 & Shareholders rights & 1.78 & 0.38 & Very low & 6 \\
\hline 3 & Equal treatment of shareholders & 2.95 & 0.28 & Medium & 2 \\
\hline 4 & $\begin{array}{l}\text { Responsibility of the Board of } \\
\text { Directors (University Council) }\end{array}$ & 3.75 & 0.30 & high & 1 \\
\hline 5 & $\begin{array}{l}\text { Beneficiaries' role in the } \\
\text { corporate governance }\end{array}$ & 2.71 & 0.61 & Medium & 3 \\
\hline 6 & Disclosure and transparency & 2.62 & 0.76 & Medium & 4 \\
\hline The principles total mean & 2.65 & 0.52 & Medium & - \\
\hline
\end{tabular}

Table 1 shows that the indicators of practicing governance in Saudi universities in the light of the principles of OECD were medium with mean (2.65). Responsibility of the Board of Directors (University Council) achieved the first rank with mean (3.75) and high degree of practice. Shareholders right got the sixth rank with a mean of (1.78) and a very low degree of practice. It can be attributed to lack of governance common practices in the public sector and fear of failure of their application, compared to the private sector. In addition, the patterns of public sector administration, systems weakness and lack of adopting practices commensurate with the national vision resulted in weak practice of governance principles at Saudi universities.

The following section introduces a description of the sample responses to each principle:

\subsection{Principle 1: Institutional Framework of Effective Corporate Governance}


Table 2. Mean and standard deviations of the first principle

\begin{tabular}{|c|c|c|c|c|c|}
\hline S. & Item & Ranking & Mean & Std. deviation & Response \\
\hline 3 & $\begin{array}{l}\text { National policies that encourage } \\
\text { investment in university activities }\end{array}$ & 1 & 3.36 & 0.96 & Medium \\
\hline 4 & $\begin{array}{l}\text { External controls governing business } \\
\text { performance at the university }\end{array}$ & 2 & 3.19 & 0.59 & Medium \\
\hline 12 & $\begin{array}{l}\text { An integrated system of supervision and } \\
\text { accountability applied to all decision makers }\end{array}$ & 3 & 2.61 & 0.71 & Medium \\
\hline 2 & $\begin{array}{l}\text { National policies promote the optimal use of } \\
\text { resources and achieve sustainable development }\end{array}$ & 4 & 2.58 & 0.69 & Low \\
\hline 1 & $\begin{array}{l}\text { National legal and regulatory environment that } \\
\text { supports relations among the university shareholders }\end{array}$ & 5 & 2.56 & 0.71 & Low \\
\hline 8 & $\begin{array}{l}\text { Standards for local and international accreditation } \\
\text { for evaluating university performance }\end{array}$ & 6 & 2.4 & 0.89 & Low \\
\hline 11 & $\begin{array}{l}\text { University by-laws and regulations determine } \\
\text { the appropriate penalties for violations against } \\
\text { all parties without discrimination }\end{array}$ & 7 & 2.35 & 0.48 & Low \\
\hline 10 & $\begin{array}{l}\text { University by-laws and regulations } \\
\text { allow active participation }\end{array}$ & 8 & 2.23 & 1.03 & Low \\
\hline 9 & $\begin{array}{l}\text { University financial resources negatively } \\
\text { affect by-laws and regulations }\end{array}$ & 9 & 2.19 & 0.71 & Low \\
\hline 5 & $\begin{array}{l}\text { There are by-laws, regulations and procedures } \\
\text { governing university performance }\end{array}$ & 10 & 2.05 & 0.82 & Low \\
\hline 13 & $\begin{array}{l}\text { There is a detailed handbook of the } \\
\text { university work procedures }\end{array}$ & 11 & 2.04 & 0.83 & Low \\
\hline 6 & $\begin{array}{l}\text { University work governed by a set of competent } \\
\text { councils and committees }\end{array}$ & 12 & 1.3 & 0.46 & Very low \\
\hline 7 & There is a strategic plan for the university & 13 & 1.02 & 0.19 & Very low \\
\hline \multicolumn{3}{|c|}{ Overall average } & 2.30 & 0.43 & Low \\
\hline
\end{tabular}

Table 2 indicates that the indicators of practicing the first principle are (low) with mean (2.30). The result can be interpreted that universities do not to adopt the principles of corporate governance and its requirements, such as policies, bylaws, regulations, institutional documents and funds that contribute to the success of its applications. The result is consistent with Information Network on Education in Europe Eurydice (2008), Al-Abbas (2009), Mok, (2010), 
Mungiu and Dusu (2011), Arab Organization for Education, Culture and Science (2013), and Al-Farra (2013). However, the result is inconsistent with Shunnaq (2009), Wang (2010), Al-Zahrani (2011), Al-Arini (2013) and Sharaf (2015).

\subsection{Principle 2: Shareholders'Rights}

Table 3. Means and standard deviations of the second principle

\begin{tabular}{|c|c|c|c|c|c|}
\hline S. & Item & Ranking & Mean & Std. deviation & Response \\
\hline 16 & $\begin{array}{l}\text { University has its own financial resources that } \\
\text { contribute to the achievement of its mission }\end{array}$ & 1 & 3.52 & 0.97 & High \\
\hline 19 & $\begin{array}{l}\text { University participates in universities global } \\
\text { rankings to enhance its reputation }\end{array}$ & 2 & 2.79 & 0.99 & Medium \\
\hline 15 & $\begin{array}{l}\text { University relies entirely on financial } \\
\text { support from the government }\end{array}$ & 3 & 1.34 & 0.48 & Very low \\
\hline 17 & $\begin{array}{l}\text { University policies are in line with } \\
\text { government policies and trends }\end{array}$ & 4 & 1.06 & 0.24 & Very low \\
\hline 14 & $\begin{array}{l}\text { University is a public sector and subjects } \\
\text { to its regulations and policies }\end{array}$ & 5 & 1 & 0.00 & Very low \\
\hline 18 & $\begin{array}{l}\text { University has an annual budget within } \\
\text { the state budget }\end{array}$ & 6 & 1 & 0.00 & Very low \\
\hline \multicolumn{3}{|c|}{ Overall average } & 1.79 & 0.38 & Very low \\
\hline
\end{tabular}

Table 3 indicates that the indicators of practicing the second principle are (very low) with an arithmetic average of (1.79). It can be attributed to the fact that universities are not subject to the system of stakes, and rely entirely on governmental funds through which it can carry out its various functions, especially the emerging universities. In addition to the lack of boards of trustees through which the joint-stock system of university assets can be activated. The result is consistent with Information Network on Education in Europe Eurydice (2008), Henard and Mitterle (2008), Al-Abbas (2009), Kpis (2009), Mok (2010), Mungiu and Dusu (2011), Barqan and Al-Qurashi (2012) and Al-Farra (2013).

However, it is inconsistent with Sharaf (2015), Al-Arini (2013), Al-Zahrani (2011), Shunnaq (2009) and Wang (2010).

\subsection{Principle 3: Equal Treatment of Shareholders}


Table 4. Means and standard deviations of the third principle

\begin{tabular}{|l|l|l|l|l|l|}
\hline S. & Item & Ranking & Mean & Std. deviation & Response \\
\hline 21 & $\begin{array}{l}\text { University Board of Trustees is concerned } \\
\text { with developing the general policy }\end{array}$ & 1 & 4.98 & 0.13 & Very high \\
\hline 22 & $\begin{array}{l}\text { Equal treatment of stakeholders inside } \\
\text { and outside the university }\end{array}$ & 2 & 2.88 & 0.83 & Medium \\
\hline 20 & The university is subject to joint-stock system & 3 & 1 & 0.00 & Very low \\
\hline Overall average & & 2.95 & 0.28 & Medium \\
\hline
\end{tabular}

Table 4 shows that the indicators of practicing the third principle are medium with a mean of (2.95). The result is unexpected due to absence of joint-stock system in Saudi universities and their dependence on the public sector system. In this system, the state policy and requirements adopted by the university administration. Consequently, result of the sample response to the third principle of 'Equal treatment of stakeholders' was expected to be very low. The result is consistent with Al-Arini (2013). Nevertheless, it is inconsistent with Information Network on Education in Europe Eurydice (2008), Henard and Mitterle (2008), Kpis (2009), Al-Abbas (2009), Shunnaq (2009), Mok (2010), Wang (2010), Al-Zahrani (2011), Mungiu and Dusu (2011), Barqan and Qurashi (2012), Al-Arini (2013), Al-Farra (2013), Sharaf (2015).

9.4 Principle 4: Responsibility of the Board of Directors (University Council) 
Table 5. Means and standard deviations of the fourth principle

\begin{tabular}{|l|l|l|l|l|l|}
\hline S. & Item & Ranking & Mean & Std. deviation & Response \\
\hline 29 & Publicizing the Board decisions to stakeholders & 1 & 4.1 & 0.35 & High \\
\hline 30 & $\begin{array}{l}\text { Applying accountability on individual } \\
\text { and collective levels }\end{array}$ & 2 & 3.89 & 0.31 & High \\
\hline 25 & Fair treatment for all university parties & 3 & 3.84 & 0.37 & High \\
\hline 26 & $\begin{array}{l}\text { Application of ethical standards in } \\
\text { university performance }\end{array}$ & 4 & 3.84 & 0.37 & High \\
\hline 27 & The objective and independent judgment on subjects & 5 & 3.84 & 0.37 & High \\
\hline 24 & $\begin{array}{l}\text { Working according to complete and } \\
\text { accurate information systems }\end{array}$ & 6 & 3.66 & 0.48 & High \\
\hline 28 & $\begin{array}{l}\text { Adopting democracy in the Board } \\
\text { administration and decisions }\end{array}$ & 7 & 3.54 & 0.50 & High \\
\hline 23 & $\begin{array}{l}\text { Approving bylaws, regulations and policies } \\
\text { governing university performance }\end{array}$ & 8 & 3.26 & 0.44 & Medium \\
\hline Overall average & & 3.75 & 0.30 & Big \\
\hline
\end{tabular}

Table 5 indicates that the indicators of practicing the fourth principle got a (high) degree with an arithmetic mean of (3.75). The result is expected due to the university council power to enact legislation, regulations and laws, and to take various decisions related to educational, research and community service functions. The result is consistent with Shunnaq (2009), Wang (2010), Al-Zahrani (2011), Sharaf (2015). However, it is inconsistent with Information Network on Education in Europe Eurydice (2008), Henard and Mitterle (2008), Al-Abbas (2009), Kpis (2009), Mok (2010), Mungiu and Dusu (2011), Barqaaan and Al-Qurashi (2012), Al-Farra (2013) and Arini (2013).

\subsection{Principle 5: Beneficiaries'Role in the Corporate Governance}


Table 6. Means and standard deviations of the fifth principle

\begin{tabular}{|c|c|c|c|c|c|}
\hline S. & Item & Ranking & Mean & Std. deviation & Response \\
\hline 39 & $\begin{array}{l}\text { Representing stakeholders in various } \\
\text { governance boards }\end{array}$ & 1 & 4.81 & 0.45 & Very high \\
\hline 45 & Continuous training of stakeholders at the university & 2 & 3.92 & 0.77 & High \\
\hline 41 & Caring of the morale of stakeholders & 3 & 3.74 & 1.00 & High \\
\hline 40 & Stakeholder awareness of roles assigned to them & 4 & 3.54 & 0.95 & High \\
\hline 42 & $\begin{array}{l}\text { The prevalence of dialogue among } \\
\text { the university stakeholders }\end{array}$ & 5 & 3.06 & 0.79 & Medium \\
\hline 34 & Providing information to stakeholders in a timely manner & 6 & 3.02 & 0.83 & Medium \\
\hline 37 & $\begin{array}{l}\text { The scientific content complies with } \\
\text { development requirements and needs }\end{array}$ & 7 & 3.01 & 0.84 & Medium \\
\hline 32 & $\begin{array}{l}\text { Allowing participation in decision-making } \\
\text { and the development of participatory mechanisms }\end{array}$ & 8 & 2.98 & 0.98 & Medium \\
\hline 38 & $\begin{array}{l}\text { There are clear mechanisms for claiming } \\
\text { rights to stakeholders }\end{array}$ & 9 & 2.85 & 0.87 & Medium \\
\hline 33 & $\begin{array}{l}\text { Respect for the rights of stakeholders and } \\
\text { compensation in case of violation }\end{array}$ & 10 & 2.73 & 0.96 & Medium \\
\hline 31 & $\begin{array}{l}\text { Achieving the interests of various stakeholders } \\
\text { in accordance with laws and regulations }\end{array}$ & 11 & 2.15 & 0.90 & Low \\
\hline 35 & $\begin{array}{l}\text { Faculty appointments carried out on objective, } \\
\text { professional and competitive grounds }\end{array}$ & 12 & 1.66 & 0.69 & Very low \\
\hline 36 & $\begin{array}{l}\text { Student admission is based on national } \\
\text { standards and university potentials }\end{array}$ & 13 & 1.29 & 0.46 & Very low \\
\hline 43 & $\begin{array}{l}\text { Staff selection is subject to the official state regulations } \\
\text { and procedures and university requirements }\end{array}$ & 14 & 1 & 0.00 & Very low \\
\hline 44 & Employees feel job security at the university & 15 & 1 & 0.00 & Very low \\
\hline \multicolumn{3}{|c|}{ Overall average } & 2.71 & 0.61 & Medium \\
\hline
\end{tabular}

Table 6 indicates that the degree of practicing of the fifth principle is (medium) with an overall average of (2.71). The result can be attributed to the nature of the university work which is based on formal and informal councils, standing and temporary committees, conferences, forums, Seminars, etc. which require the participation of as many stakeholders including students, faculty, employees and community institutions. The result is consistent with Al-Arini (2013). It is inconsistent with Information Network on Education in Europe Eurydice (2008), 
Al-Abbas (2009), Mok (2010), Wang (2010), Al-Zahrani (2011), Mungiu and Dusu (2011), Arab Organization for Education, Culture and Science (2013), Al-Farra (2013), and Sharaf (2015).

\subsection{Principle 6: Disclosure and Transparency}

Table 7. Means and standard deviations of the sixth principle

\begin{tabular}{|c|c|c|c|c|c|}
\hline S. & Item & Ranking & Mean & Std. deviation & Response \\
\hline 56 & Disclosure of misconduct by officials & 1 & 4.52 & 0.52 & Very high \\
\hline 57 & $\begin{array}{l}\text { Accountability of personnel responsible for } \\
\text { any legal or administrative irregularities }\end{array}$ & 2 & 4.31 & 0.77 & Very high \\
\hline 51 & Disclosure of the core risks that threaten the university & 3 & 3.64 & 0.91 & High \\
\hline 65 & Performance assessment for university stakeholders & 4 & 3.23 & 0.95 & Medium \\
\hline 47 & Disclosure of accountability mechanisms & 5 & 3.04 & 0.84 & Medium \\
\hline 50 & $\begin{array}{l}\text { Transparent disclosure of the } \\
\text { University Council decisions }\end{array}$ & 6 & 2.91 & 0.90 & Medium \\
\hline 46 & Disclosure of the University's policies & 7 & 2.85 & 0.92 & Medium \\
\hline 54 & Disclosure of community responsibilities & 8 & 2.73 & 0.99 & Medium \\
\hline 62 & $\begin{array}{l}\text { Activating the principle of reward and } \\
\text { punishment among employees }\end{array}$ & 9 & 2.69 & 0.91 & Medium \\
\hline 61 & University problems handled with great transparency & 10 & 2.66 & 0.94 & Medium \\
\hline 55 & Disclosure in various mass media & 11 & 2.51 & 0.99 & Low \\
\hline 58 & Performance indicators for each job and employee & 12 & 2.44 & 0.94 & Low \\
\hline 52 & Disclosure of Annual Budgets (Revenues and Expenses) & 13 & 2.42 & 0.99 & Low \\
\hline 59 & The University adopts clear regulations and instructions & 14 & 2.02 & 0.86 & Low \\
\hline 48 & There is an internal audit department & 15 & 2.02 & 0.94 & Low \\
\hline 60 & Responsibilities of the University councils are clear & 16 & 1.92 & 0.77 & Low \\
\hline 63 & There are many student clubs & 17 & 1.8 & 0.83 & Very low \\
\hline 49 & Facilitating the functions of external audit departments & 18 & 1.77 & 0.79 & Very low \\
\hline 64 & $\begin{array}{l}\text { The University provides a system for receiving and } \\
\text { handling stakeholder proposals and complaints }\end{array}$ & 19 & 1.76 & 0.84 & Very low \\
\hline 53 & Disclosure of strategic and operational plans & 20 & 1.16 & 0.43 & Very low \\
\hline \multicolumn{3}{|c|}{ Overall average } & 2.62 & 0.76 & Medium \\
\hline
\end{tabular}




\section{Macrothink

Table 7 indicates that the degree of indicators of practicing the sixth principle is (medium) with mean (2.62). The result is attributed to the strong influence of stakeholders, their role in the university performance and their awareness of their rights largely. The nature of the university system, which is based on councils, committees and teams as well as internal and external control bodies enhance accountability. Globalization, information availability and diversity of means of communication and social media represent an informal authority for universities disclosure and accountability.

The result is consistent with Al-Arini (2013). It is inconsistent with Information Network on Education in Europe Eurydice (2008), Al-Abbas (2009), Mok (2010), Wang (2010), Al-Zahrani (2011), Mungiu and Dusu (2011), Arab Organization for Education, Culture and Science (2013), Al-Farra (2013) and Sharaf (2015).

To answer the second question: What are the challenges facing governance practice in Saudi universities? Means and standard deviation for the sample responses to the challenges facing the application of the principles of governance in Saudi universities are calculated. 
Table 8. Means and standard deviations of the challenges facing governance practice in Saudi universities

\begin{tabular}{|c|c|c|c|c|c|}
\hline S. & Item & Ranking & Mean & Std. deviation & Response \\
\hline 9 & University dependence on the public sector policies & 1 & 5 & 0.00 & Very high \\
\hline 10 & $\begin{array}{l}\text { Absence of university shareholder systems } \\
\text { and procedures }\end{array}$ & 2 & 5 & 0.00 & Very high \\
\hline 8 & Lack of effective governance principles for universities & 3 & 4.98 & 0.13 & Very high \\
\hline 11 & University relies on government support in its budgets & 4 & 4.9 & 0.67 & Very high \\
\hline 1 & $\begin{array}{l}\text { Lack of written document for the practice of } \\
\text { effective governance at the university }\end{array}$ & 5 & 4.85 & 0.36 & Very high \\
\hline 4 & $\begin{array}{l}\text { Administrative structures do not include } \\
\text { governance departments }\end{array}$ & 6 & 4.77 & 0.64 & Very high \\
\hline 13 & $\begin{array}{l}\text { Prevalence of bureaucratic practices in } \\
\text { university performance }\end{array}$ & 7 & 4.02 & 0.13 & High \\
\hline 14 & $\begin{array}{l}\text { Weak participation of the university stakeholders } \\
\text { in decision-making process }\end{array}$ & 8 & 4.01 & 0.09 & High \\
\hline 5 & $\begin{array}{l}\text { Poor awareness of the importance of practicing } \\
\text { governance in achieving quality }\end{array}$ & 9 & 3.81 & 0.67 & High \\
\hline 2 & $\begin{array}{l}\text { Weak application of effective governance } \\
\text { systems in universities }\end{array}$ & 10 & 3.81 & 0.92 & High \\
\hline 12 & $\begin{array}{l}\text { Weak financial allocations for the implementation } \\
\text { of university's governance systems }\end{array}$ & 11 & 3.63 & 0.52 & High \\
\hline 6 & $\begin{array}{l}\text { Weak dialogue councils at the university at } \\
\text { different levels }\end{array}$ & 12 & 3.46 & 0.77 & High \\
\hline 15 & $\begin{array}{l}\text { Weak policies that promote integrity, transparency } \\
\text { and accountability in the provision of public } \\
\text { services to beneficiaries }\end{array}$ & 13 & 3.2 & 0.91 & Medium \\
\hline 7 & $\begin{array}{l}\text { Weak spending and collection procedures } \\
\text { at the university }\end{array}$ & 14 & 3.15 & 0.91 & Medium \\
\hline 3 & $\begin{array}{l}\text { Some officials are not convinced of the exercise of } \\
\text { effective governance }\end{array}$ & 15 & 3.1 & 0.99 & Medium \\
\hline \multicolumn{3}{|c|}{ Overall average } & 4.11 & 0.39 & High \\
\hline
\end{tabular}

Table 8 indicates that challenges facing the practice of governance in Saudi universities got a (high) degree with a mean (4.11), ranged from (3.1-5). The result is expected due to a count of 
reasons, including lack of official advertising on the public sector and university level about the trend towards governance applications and lack of governance principles and rules in universities. In addition, some officials are afraid of applying the principles of governance as they are convinced of its inappropriateness to the practices of academic work. The result is consistent with Henard and Mettarle (2008), Kpis (2009), Barqan and Al-Qurashi (2012) and Al-Farra (2013). However, it is inconsistent with Al-Arini (2013) and Sharaf (2015).

To answer the third Question: What are the proposed principles for governance in Saudi universities? A tool has been designed to ask the opinion of (25) education experts in Saudi universities on the proposed principles of university governance. Frequencies and percentages of (appropriate and inappropriate) degrees calculated. Results showed that the proposed principles are appropriate with $99 \%$ and higher, which means the education experts support the proposed principles.

\section{The Proposed Principles of Saudi Universities Governance}

\subsection{The Proposed Starting Points}

The majority of the sample agreed that the five starting points of the proposed model are appropriate with a high percentage of $98.66 \%$. The agreement rates for each point, ranked from highest to lowest, were as follows:

1) Saudi government is moving toward the reconstruction of the public sector $(100 \%)$.

2) Saudi government adopting a policy of anti-corruption and enhancing integrity (100\%).

3) Saudi Arabia vision 2030 focuses on efficient performance (100\%).

4) Saudi government adopting a policy of efficient financial spending and resources optimal use $(100 \%)$.

5) Scientific trends towards the application of effective governance in public sectors $96 \%$.

6) Saudi government is moving toward the privatization of the public sector (96\%).

\subsection{Justifications for the Proposal}

The sample agreed that the six justifications for the proposed model are suitable with a high percentage reached $(100 \%)$ and the agreement rate for each point was $100 \%$, as follows:

1) Global trends to focus on effective governance practices.

2) Lack of principles of effective governance in universities.

3) Linking effective governance practices to improving the quality of university output.

4) Poor governance practices in universities.

5) Contribution of effective governance practices in achieving sustainable progress.

6) Applicability of the proposed model in universities. 
10.3 Objectives of the Proposal

Most of the sample agreed on the four goals objectives of the proposed model with $99 \%$, agreement rate for each objective, ranked from highest to lowest, as follows:

1) Developing the performance of university units in the practice of effective governance $(100 \%)$.

2) Identifying shortcomings between the reality and the standards of practicing effective governance in universities $(100 \%)$.

3) Overcoming the challenges that face the optimal use of resources $100 \%$.

4) Strengthening university administrations capacity for practicing effective governance $(96 \%)$.

\subsection{Proposed Principles for University Governance Practices}

\subsubsection{Legal Framework (Regulations, Laws and Procedures)}

The sample totally agreed that the 14 indicators are appropriate with (100\%); each indicator got $100 \%$, as follows:

1) A national and regulatory legal environment protects functional relations.

2) National policies encourage investment in university activities.

3) A legal framework has a positive impact on university performance.

4) Legal and regulatory requirements within legislative jurisdiction.

5) Clear distribution of responsibilities among relevant bodies with the university.

6) University units have the authority to manage their functions.

7) University units have the resources required for carrying out their duties.

8) University is subject to a Board of Trustees, as supreme authority.

9) Community sectors participate in multiple governance boards within the university.

10) University has a regular strategic plan.

11) University has internal performance standards.

12) University responds to external performance standards

13) Monitoring, disclosure and accounting systems are available in university.

14) Availability of documents of basic requirements of work procedures.

10.4.2 Stakeholders Rights (Students, Faculty, Employees, Private Sector, Community, Government)

Most of the sample agreed with a total rate of (99.47\%) on the appropriateness of (61) indicator, 


\section{Macrothink}

they are arranged in descending order in the following section:

Respondents agreed on student right indicators by $100 \%$, regarding his/her right to:

1) Respect of his/her rights according to laws and regulations.

2) Get information in time.

3) Participate in taking decisions and facilitate its mechanisms.

4) Have compensation, in case of violating one of his/her rights.

5) Clarify the roles assigned to him/her.

6) Strengthen his/her morale.

7) Be encouraged to dialogue

8) Have access to university services

9) Practice student activities

10) Have encouragement bonuses.

11) Acquire sufficient knowledge and skill.

12) Have good treatment

13) Have the appropriate university environment.

14) Select the appropriate faculty member.

15) Express creativity and innovation.

Respondents agreed on faculty right Indicators by $100 \%$, however four items got a lower percentage, ranging between ( $92 \%$ - 96\%), represented in his/her right to:

16) Respect of his/her rights according to laws and regulations.

17) Get information in time.

18) Participate in taking decisions and facilitate its mechanisms.

19) Have compensation, in case of violating one of his/her rights.

20) Clarify the roles assigned to him/her.

21) Strengthen his/her morale.

22) Intellectual independence

23) Have the adequate supporting tools

24) Have a return in accordance with his/her experience.

25) Participate in building knowledge and skill content. 
26) Participate in community development.

27) Accept or refuse administrative work.

28) Participate in conferences and seminars.

29) Develop his/her skills.

30) Protect his/her intellectual property.

31) Have academic freedom $(92 \%)$.

32) Have scientific promotions (92\%)

33) Participate in leadership selection (96\%)

34) Job mobility among universities (96\%)

Employee rights indicators got (100\%) agreement rate, while one item obtained $(92 \%)$, represented in his/her right to:

35) Respect of his/her rights according to laws and regulations.

36) Get information in time.

37) Participate in taking decisions and facilitate its mechanisms.

38) Have compensation, in case of violating one of his/her rights.

39) Clarify the roles assigned to him/her.

40) Strengthen his/her morale.

41) Have appropriate financial return for post tasks.

42) Have annual incentive bonuses.

43) Join training and rehabilitation programs.

44) Receive advice and guidance.

45) Express creativity in the field of work.

46) Job mobility.

47) Enjoy vacation on time (92\%).

The indicators of the private sector, community and government rights obtained $100 \%$ agreement rate, represented in the private sector rights as following:

48) Respect of rights according to laws and regulations.

49) Get information in time.

50) Participate in taking decisions and facilitate its mechanisms.

51) Clarify its assigned roles. 
52) Participate in fair competition for investment opportunities.

The society rights to:

53) Respect of rights according to laws and regulations.

54) Get information in time.

55) Participate in taking decisions and facilitate its mechanisms.

56) Clarify its assigned roles.

57) Achieve the development needs.

The government rights to:

58) Respect of rights according to laws and regulations.

59) Get information in time.

60) Achieve the development needs.

61) Stakeholders feel safe from risks.

10.4.3 Independence and Academic Freedom

The sample agreed on the appropriateness of the indicators of this principle by a high percentage of $100 \%$, as follows:

1) Administrative independence.

2) Financial independence.

3) Academic independence.

4) Intellectual freedom.

5) Scientific Research Freedom.

6) Joining scientific societies Freedom.

\subsubsection{Fairness and Equality}

The sample agreed on the appropriateness of the indicators of this principle by a high rate of $100 \%$, represented in achieving fairness and equality in:

1) Taking procedure.

2) Enforcing morality.

3) Distribution.

4) Treatment.

5) Equal opportunities.

6) Evaluation. 


\section{Macrothink}

10.4.5 Responsibility and Accountability

The sample agreed on the appropriateness of the indicators of this principle by a high rate of $100 \%$, as follows:

1) Making decisions according to information.

2) Presentation of policies and decisions.

3) Applying performance standards for each activity.

4) Independent subjective judgment.

5) Developing performance indicators for university employees.

6) Control system ensures achievement.

7) An internal audit system.

8) Facilitating the functions of external reviewers.

9) An integrated accounting system for employees, units and councils.

10) Accountability and banishment of violators

10.4.6 Disclosure and Transparency

The sample agreed on the appropriateness of the indicators of this principle by a high rate of $100 \%$, as following:

1) Disclosure of policies, plans and regulations.

2) Interactive website.

3) Databases for beneficiaries immediate services.

4) Publicizing the university policies and decisions constantly.

5) Publicizing performance and achievement reports annually.

6) Publicizing admission criteria for students and recruitment for employees clearly.

7) Disclosure of decisions to beneficiaries.

8) Disclosure of illegal behaviors.

9) Disclosure of annual budgets.

10) Disclosure of the potential risks.

10.4.7 Adequacy and Effectiveness

The sample agreed on the appropriateness of the indicators of this principle by a high rate of $100 \%$, as following:

1) Declaration of its short- and long-term objectives. 


\section{IIacrothink

2) Developing the skills of its administrative, educational and research staff.

3) Investing its financial resources efficiently and effectively.

4) Achieving its objectives through its direct decisions.

5) Providing accurate job specification.

6) Adhering to strict recruitment standards for all employees.

7) Encouraging participation, teamwork and professional committees.

8) Seeking to achieve its objectives at minimum cost and time.

9) Moving towards administrative decentralization.

10) Prevalence of democratic leadership style in the university.

11) Focusing on a particular university model to achieve competitive advantage.

10.5 Mechanisms for Applying the Proposal

The sample agreed on the appropriateness of the indicators of this principle by a high rate of $100 \%$, as following:

1) University administrations adopt the proposed governance principles.

2) Developing organizational structures of universities and their organizational units by adding a governance department.

3) Developing professional performance standards for effective governance in universities.

4) Preparing a handbook for governance procedures at the university.

5) Preparing the operational plans for governance units in universities.

6) Developing internal administrative, financial and academic control systems in universities.

7) Preparing accurate job specifications for university positions.

8) Preparing accurate work procedures handbooks.

9) Reviewing contracts and agreements in the light of governance standards adopted by the university.

10) Granting independence and absolute powers to the governance units in the universities.

11) Achieving consistency between governance standards and quality standards.

12) Achieving consistency between governance units and internal audit units in universities.

13) Preparing periodic reports by corporate governance units on the level of compliance with the principles of governance.

\section{Recommendations}




\section{Macrothink}

1) Disseminating the culture of governance in Saudi universities, providing is requirements and preparing the environment for its practice.

2) Benefiting from the proposed principles for the practice of governance in Saudi universities, which have been subject to the opinion of a big number of education experts and those who are particularly concerned with the application of governance.

3) Attempting to overcome the challenges facing the practice of governance in Saudi universities.

\section{Suggestions}

1) Conducting a similar study to be applied to other Saudi universities.

2) Conducting a similar study to be applied to private Saudi universities.

\section{References}

Abdullah, A. A. (2009). Governance and effective management: A Tool for Reform and Development Support in the Arab Region. Publications for distribution and publication, Beirut, Lebanon.

Abu Bakr, M. M. (2005). Regulatory and administrative requirements for effective application of governance in public Universities. A Paper Introduced to the Conference of Corporate Governance and its Administrative Accounting Dimensions, Faculty of Commerce, Alexandria, Egypt.

Abu Dhabi Governance Center. (2016). Governance concepts and principles: A series of educational publications for Abu Dhabi Governance Center. Abu Dhabi: United Arab Emirates.

Al-Abbas, M. (2009). University governance: Analytical study. A paper presented Conference on Corporate Governance: Current practices and future prospects, King Khalid University, Abha, Saudi Arabia.

Al-Arini, M. A. (2014). The reality of applying governance from staff and faculty's perspectives in Imam Muhammad bin Saud Islamic University. International Journal of specialized Education, 3(12).

Al-Essa, I. S., et al. (2013). University Governance Models. Saudi Journal of Higher Education, 10.

Al-Farra, M. M. (2013). Governance challenges in Palestinian higher education institutions: Case study of Colleges of Economics and administration in Gaza. Research paper presented to the Third Arab International Conference for Quality Assurance of Higher Education, Zaytuna University, Jordan.

Al-Fawzan, J. S. (2017). A framework for activating governance in Saudi universities to achieve Vision 2030. Working paper submitted to Conference of the role of Saudi universities in activating Vision 2030, 11-12 January, Al-Qassim University, Saudi Arabia. 
Al-Kayed, Z. A. (2003). Governance: Issues and Applications (1st ed.). OECD Publications.

Altwaijri, A. A. (2009). Weakness of academic performance: Reasons and treatment applied to students of Economics and Administration, Al-Qassim University. Public Administrative Journal, 49(3),

Al-Zahrani, K. M. (2011). The reality of applying effective governance in Saudi private universities and their relation to job satisfaction and organizational loyalty among faculty ( $\mathrm{PhD}$ thesis, Umm Al-Qura University, Saudi Arabia).

Arab Organization for Education, Culture and Science. (2013). Patterns of educational systems governance and their impact on educational institutions management and quality assurance services. Education Indicators Project in the Arab World, Arab Monitor, Department of Education, Tunisia.

Barqan, A., \& Al-Qurashi, A. (2012). Globalization of management in the era of globalization. A paper presented to the International Scientific Conference, December 15-17, 2012, Jinan University, Lebanon.

Bilal, M. (2005). The role of quality review control in achieving corporate quality objectives. Fifth Conference of Corporate Governance and its Administrative Accounting Dimensions, Faculty of Commerce, Alexandria, Egypt.

Dahawi, M., \& Bioumy, M. R. (2011). A comparative study of institutional governance of universities in South Africa and Zimbabwe and its potential application in Egypt. $19^{\text {th }}$ Scientific Conference of the Egyptian Association for Education, Comparison and Educational Management, Cairo, Egypt.

Ezzat, A. (2009). The concept of university governance, its purpose and means of application. Amman: Jordan.

Gawdat, F. A. (2008). Applying the principles of corporate governance in Palestinian banks according to the principles of OECD and Basel Committee on Banking Supervision (Master Thesis, Islamic University, Gaza, Palestine).

Ghader, M. Y. (2012). Governance determinants and standards. Paper presented to the International Scientific Conference: Globalization of Management in an Era Knowledge, December, 15-17, 2012, Al-Jinan University, Tripoli, Lebanon.

Ghaleb, R., \& Alem, T. (2008). Faculty professional development: entrance to total quality of university education. Arabic Journal of Quality Insurance in Higher Education, 1(11).

Glenn, N. G. (2008). Leveraging quality improvement to achieve student learning assessment success in higher education. University of Marlyland, ProQuest LLC.

Hafez, M. A. (2011). Work force governance. Al-Fajer House for Publication, Cairo, Egypt.

Hamada, T. A. (2010). The role of universities in spreading the culture of governance in society and developing mechanisms to combat administrative financial corruption. Working paper presented to the First International Conference on Accounting and Auditing against Corruption, 
April 7-8, 2010, Beni-Sweif University, Egypt.

Henard, F., \& Mitterle, A. (2008). Governance and quality in higher education, education program on institutional management in higher education. France: OECD.

Jezierska, J. (2009). Policies in the European higher education a rea: A comparative case study. Quality assurance. University of Nevada, Las Vegas.

KPIS. (2009). Key performance indicators for governance of public university in Malaysia. Asian Center for Research and University Learning and Teaching.

Marzouk, F. J. (2012). Open education governance: Strategic perspective (1st ed.). Anglo-Egyptian Library: Egypt.

Mohammed, M. F. (2011). Analytical study of the concept of effective governance and its application requirements in Egyptian universities. Arab Education Future, 18(72).

Mok, K. H. (2010). When state centralism meets neo-liberalism managing university governance change in Singapore and Malaysia higher Education. The World Bank: Trends developing economic (pp. 419-440). Africa Region Human Development, Washington. https://doi.org/10.1007/s10734-009-9307-9

Mungiu, P., \& Dusu, A. E. (2011). Civil society and control of corruption Assessment governance of Romanian public universities. International Journal of Educational Development, 526-540.

Nassereldeen, Y. A. (2012). The reality of applying governance in the Middle East University. Publications of the Middle East University, Amman.

OECD (Organization for Economic Co-operation and Development). (2010). Report of the Organization for Economic Cooperation and Development. Ministry of Higher Education: Egypt.

Sharaf, H. S. (2015). The reality of applying governance systems and obstacles in Palestinian universities from faculty deans' and department heads' perspectives in the West Bank (Master Thesis, An-Najah National University, Palestine).

Shehata, H. (2001). University education and assessment: theory and practice. Arabic House for Books, Cairo: Egypt.

Shunnaq, R. M. (2009). Governance concept and practice degree in Jordanian private universities ( $\mathrm{PhD}$ Thesis, College of Studies Higher, University of Jordan, Amman).

Taei, A., \& Hamad, A. (2010). Dimensions of local governance in Iraq: Field study on the local board of Mahmoudyeh. Journal of Baghdad Economic College, 52.

The Information Network on Education in Europe Eurydice. (2008). Higher Education Governance in Europe Belgium European Commission, Eurydice. 


\section{Macrothink}

Journal of Educational Issues

ISSN 2377-2263

2019, Vol. 5, No. 1

Wang, L. (2010). Higher education governance and university autonomy in China societies and education. Globalisation Societies and Education Societies and Education, 4, 477-495. https://doi.org/10.1080/14767724.2010.537942

Yang, S. (2007). Academic of higher education experiences of America. Conference National University of Tainan.

Youssef, M. H. (2007). The determinants and standards of governance and their application in Egypt. A research submitted to Investment Bank, Cairo, Egypt.

\section{Copyright Disclaimer}

Copyright for this article is retained by the author(s), with first publication rights granted to the journal.

This is an open-access article distributed under the terms and conditions of the Creative Commons Attribution license (http://creativecommons.org/licenses/by/3.0/). 